\title{
Soil properties and species diversity of grazed crested wheatgrass and native rangelands
}

\author{
MAJA KRZIC, KLAAS BROERSMA, DON J. THOMPSON, AND ARTHUR A. BOMKE
}

Authors Krzic and Bomke are research associate and associate professor, Faculty of Agricultural Sciences, University of British Columbia, Vancouver, BC, Canada V6T 1Z4; Broersma and Thompson are soil scientist and range ecologist, Agriculture and Agri-Food Canada, Range Research Unit, 3015 Ord Road, Kamloops, BC, Canada V2B $8 A 9$.

\section{Abstract}

Crested wheatgrass (Agropyron cristatum (L.) Gaertn.) is an introduced grass used extensively for rangeland revegetation in the semiarid and arid regions of western North America. The long-term effects of crested wheatgrass on soil properties and plant community were evaluated on 5 grazed sites in the southern interior of British Columbia, Canada. Each site included plant communities of native bluebunch wheatgrass (Pseudoroegneria spicata (Pursh) Scribn. \& Smith) and 14- to 60year-old stands of crested wheatgrass. Soil samples and plant data were collected in June 1997. Species numbers were similar for native and crested wheatgrass rangelands, while the diversity index of crested wheatgrass rangeland was lower due to lower evenness. Crested wheatgrass and native grasses were observed to produce similar amounts of root biomass. Most soil properties were similar under the 2 rangelands. One of the exceptions was soil carbon at $0-7.5$ and $7.5-15 \mathrm{~cm}$ depths, which was higher on crested wheatgrass than native rangeland. Soil nitrogen at 15-30 cm depth was also higher on crested wheatgrass rangeland. Greater soil penetration resistance was observed at 7.5 and $9 \mathrm{~cm}$ depths on crested wheatgrass than native rangeland. Higher soil compaction was caused by grazing of crested wheatgrass earlier in the season when soils are wetter relative to the native rangeland. The results of this study indicate that seeding of crested wheatgrass combined with the long-term grazing by cattle did not result in the degradation of soil properties, but plant diversity was reduced relative to grazed native, bluebunch wheatgrass rangeland.

Key Words: Soil C, soil N, penetration resistance, aggregate stability, root biomass, bluebunch wheatgrass

Crested wheatgrass (Agropyron cristatum (L.) Gaertn.), a drought- and cold-tolerant grass from the steppes of central Asia, has been seeded on about 5 million hectares in western North America (Gomm 1981). It is an important cool-season grass, providing nutritious, early spring forage that is converted into increased livestock gains. Although advantages of crested wheatgrass as a seeded forage grass are well known, data are lacking

This work was supported by the Beef Cattle Industry Development Fund and the Matching Investment Initiative of Agriculture and Agri-Food Canada. The technical help of Bruce Roddan, Siri Sanderson, Barb Wheatley, and Norm Burns in the field and laboratory was appreciated. Helpful suggestions from Drs. MarieClaude Fortin and John Dormaar were greatly appreciated.

Manuscript accepted 18 Aug. 1999.
Resumen

El zacate "Crested wheatgrass" (Agropyron cristatum (L.) Gaertn.) es una especie introducida utilizada ampliamente para revegetar pastizales de las regiones áridas y semiáridas del oeste de Norteamérica. Se evaluaron los efectos a largo plazo del "Crested wheatgrass" en las propiedades del suelo y la comunidad vegetal, la evaluación se llevo a cabo en 5 sitios con apacentamiento localizados en el interior de Columbia Británica, Canadá. Cada sitio incluía comunidades del zacate nativo "Bluebunch wheatgrass" (Pseudoroegeneria spicata (Pursh) Scribn. \& Smith) y poblaciones de "Crested wheatgrass" de entre 14 y 60 años de edad. Las muestras de suelo y los datos de las plantas se colectaron en junio de 1997. Los números de especie fueron similares para los pastizales nativos y de "Crested wheatgrass", mientras el índice de diversidad del pastizal de "Crested wheatgrass" fue mas bajo debido a su uniformidad. Se observo que los zacates nativos y el "Crested wheatgrass" producen cantidades similares de biomasa de raíz. La mayoría de las propiedades del suelo fueron similares en los dos tipos de pastizal. Una de las excepciones fue el carbón del suelo a las profundidades de 0-7.5 y 7.5-15 cm, el cual fue mayor en el pastizal de "Crested wheatgrass" que en los pastizales nativos. El contenido de nitrógeno del suelo a la profundidad de $15-30 \mathrm{~cm}$ fue también mayor en el pastizal de "Crested wheatgrass. En el pastizal de "Crested wheatgrass" la resistencia de penetración del suelo en las profundidades de 7.5 y $9 \mathrm{~cm}$ fue mayor que la registrada en los pastizales nativos. La mayor compactación del suelo la causo el apacentamiento del "Crested wheatgrass" a inicios de la estación cuando los suelos estaban mas húmedos en relación a los suelos de los pastizales nativos. Los resultados de este estudio indican que la siembra de "Crested wheatgrass" en combinación con el apacentamiento con ganado doméstico a largo plazo no resulta en la degradación de las propiedades del suelo, pero la diversidad de especies vegetales fue reducida en relación con pastizales nativos de "Bluebunch wheatgrass" bajo apacentamiento.

regarding its long-term effects on physical and chemical properties of the soil.

Past studies comparing crested wheatgrass seedings to adjacent native rangeland have shown that crested wheatgrass is a strong competitor and usually produces a monoculture for 40 to 50 years (Looman and Heinrichs 1973, Anderson and Marlette 1986). When a native Stipa-Bouteloua community in the semiarid regions of southern Alberta was altered to a crested wheatgrass monoculture, soil quality declined as a result of decreasing root biomass, 
accompanied with less stable soil organic matter, lower aggregate stability, and higher bulk density (Smoliak et al. 1967, Dormaar et al. 1978, Dormaar et al. 1995).

Most of the previous work in Canada considering impacts of crested wheatgrass on the soil was done in southern Alberta, and no information is available for British Columbia (BC). Southern Alberta and southern interior of $\mathrm{BC}$ have somewhat similar climate and soil types, although the latter region is characterized by a greater summer water deficit. In addition, lower elevation native rangelands in the southern interior of BC are dominated by bluebunch wheatgrass (Pseudoroegneria spicata (Pursh) Scribn. \& Smith) and big sagebrush (Artemisia tridentata Nutt.), while native rangelands in southern Alberta are dominated by needle-and-thread (Stipa comata Trin. \& Rupr.) and blue grama (Bouteloua gracilis (HBK.) Lag.).

The objective of this study was to assess soil chemical and physical properties and plant community on long-term grazed stands of crested wheatgrass and adjacent stands of native rangeland dominated by bluebunch wheatgrass.

\section{Materials and Methods}

\section{Site Description}

Five sites (Table 1), each including adjacent plant communities of crested wheatgrass and native bluebunch wheatgrass, were selected in the ThompsonNicola region of BC about $150 \mathrm{~km}$ north from the Canada-US border. Soils at all sites were classified as Dark Brown Chernozem (Typic Haploboroll). The semiarid climate of the region is characterized by hot, dry summers (average temperature for June-September is $18.6^{\circ} \mathrm{C}$ ) and relatively cold winters (average temperature for November-February is $-1.8^{\circ} \mathrm{C}$ ). An average annual precipitation of 300 $\mathrm{mm}$ is bimodally distributed with peaks in
May-June and December-January (Environment Canada 1998).

\section{Sampling and Analyses}

Plant and soil samples were collected during 3-10 June 1997. Species number and foliar cover of each plant species on crested wheatgrass and native rangeland were determined within $0.25 \times 0.5 \mathrm{~m}$ frames located at every meter along 3 randomly selected transects (Daubenmire 1959). These transects were $25 \mathrm{~m}$ long and oriented along similar slopes on crested wheatgrass and native rangelands. Species-cover data were used to calculate a diversity index (Shannon and Weaver 1949) and evenness (Pileou 1966) within both rangelands. The simplest indicator of species diversity is species richness, representing the number of species encountered in a sample area. Species diversity can also be described by diversity indices, which balance species richness with another component-evenness. The evenness describes how the measure of abundance (such as cover in this study) is shared among species. Maximum evenness occurs when species abundance is equally shared between 2 species, but this may not give a high diversity index because few species are present. The Shannon-Weaver-diversity index was used since it is sensitive to changes in the abundance of less dominant species in a community (De Jong 1975).

Four soil and root sampling units were randomly selected within crested wheatgrass and native rangelands. A doublecylinder, drop-hammer sampler (with a core of $7.5 \times 7.5 \mathrm{~cm}$ ) was used to collect root samples from $0-7.5$ and $7.5-15 \mathrm{~cm}$ depths. Two cores were taken at each of the 4 sampling units and mixed to make a composite root sample. Root samples were washed, sieved through a $1-\mathrm{mm}$ sieve, dried at $65^{\circ} \mathrm{C}$ for 48 hours, and weighed. Ash content of roots was determined by ignition at $550^{\circ} \mathrm{C}$ for 4 hours and root bio- mass is reported on an ash-free, oven-dry basis. Carbon and $\mathrm{N}$ concentrations of root samples were determined by automated combustion analyzer (Carlo Erba, Milan, Italy) and calculated on an ash-free basis.

Soil samples for chemical properties were taken at $0-7.5,7.5-15$, and 15-30 $\mathrm{cm}$ depths, air-dried, and ground to pass a 2.0-mm sieve. One sample was taken per sampling unit. Total soil $\mathrm{C}$ and $\mathrm{N}$ were determined by a dry combustion method (Nelson and Sommers 1982) using an automated analyzer (Carlo Erba, Milan, Italy). Content of total soil polysaccharides was determined by the phenol-sulfuric acid method of Dubois et al. (1956) as modified by Doutre et al. (1978). Light fraction was isolated by flotation on sodium iodide at a density of $1.7 \mathrm{~g} \mathrm{~cm}^{-3}$ (Gregorich and Ellert 1993). Total soil P was determined by the Parkinson and Allen (1975) method, while available P was determined on a sodium bicarbonate $\left(\mathrm{NaHCO}_{3}\right)$ extract (Olsen et al. 1954). Soil cation exchange capacity (CEC) and exchangeable cations $(\mathrm{Ca}, \mathrm{Mg}, \mathrm{K}$, and $\mathrm{Na}$ ) were determined by the ammonium acetate $(\mathrm{pH} 7)$ method (Soil Survey Laboratory Staff 1992). Soil pH was determined on a $1: 2(\mathrm{v} / \mathrm{v})$ soil to $0.01 \mathrm{M} \mathrm{CaCl}_{2}$ slurry (McLean 1982).

Three soil samples were taken from the $0-7.5 \mathrm{~cm}$ depth on each of the 4 randomly selected sampling units and mixed to make a composite sample for aggregate stability analysis. The soil structural stability was assessed using a variation of the wet sieving method (Yoder 1936). Moist samples collected from the field were sieved using a 6-mm sieve and collected on a $2-\mathrm{mm}$ sieve. The pre-sieved $2-6 \mathrm{~mm}$ moist sample (of about $10 \mathrm{~g}$ ) was placed on the top of a nest of sieves with openings of $2.00,1.00$, and $0.25 \mathrm{~mm}$ and wetted in a humidifier for 1 hour to minimize disruption caused by air trapping. This was done immediately before wet sieving. Wet sieving was performed for 10 minutes

Table 1. Location, site characteristics, and time of crested wheatgrass seeding on 5 sites in Thompson-Nicola region of British Columbia.

\begin{tabular}{|c|c|c|c|c|c|}
\hline \multirow[t]{2}{*}{ Description } & \multicolumn{5}{|c|}{ Site } \\
\hline & Tranquille ranch & Dewdrop ranch & Quilchena ranch & Harper ranch & Guichon ranch \\
\hline Longitude & $120^{\circ} 30^{\prime} \mathrm{W}$ & $120^{\circ} 33^{\prime} \mathrm{W}$ & $120^{\circ} 29^{\prime} \mathrm{W}$ & $120^{\circ} 09^{\prime} \mathrm{W}$ & $120^{\circ} 26^{\prime} \mathrm{W}$ \\
\hline Latitude & $50^{\circ} 43^{\prime} \mathrm{N}$ & $50^{\circ} 45^{\prime} \mathrm{N}$ & $50^{\circ} 09^{\prime} \mathrm{N}$ & $50^{\circ} 40^{\prime} \mathrm{N}$ & $50^{\circ} 15^{\prime} \mathrm{N}$ \\
\hline Elevation $(\mathrm{m})$ & 450 & 600 & 650 & 500 & 700 \\
\hline Precipitation for May-Sep (mm) & 125 & 125 & 150 & 175 & 150 \\
\hline Parent material & fluvial & fluvial & glaciofluvial & lacustrine & glaciofluvial \\
\hline Coarse fragments, i.e. diameter $>2 \mathrm{~mm}(\%)$ & 1 & 8 & 13 & 0 & 9 \\
\hline Soil texture & sandy loam & loam & silt loam & silt loam & loam \\
\hline Clay $(\%)$ & 8 & 21 & 17 & 10 & 13 \\
\hline Sand $(\%)$ & 62 & 38 & 29 & 13 & 48 \\
\hline Crested wheatgrass seeded & 1937 & 1968 & 1937 & 1982 & 1983 \\
\hline
\end{tabular}


in a motor-driven mechanical device with a vertical stroke of $2.5 \mathrm{~cm}$ at a rate of 30 strokes per minute. The motion of the system had both a vertical stroke and an oscillating action through an angle of $30^{\circ}$. After sieves were removed from water, the proportion of material retained on each sieve was oven dried at $105^{\circ} \mathrm{C}$ for 24 hours, weighed, and expressed as a percentage of the total soil. The results were expressed as the mean weight diameter, which represents the sum of the mean diameter of each size fraction (Di) and the proportion of the sample weight occurring in the corresponding size fraction $\left(\mathrm{W}_{\mathrm{i}}\right.$ ) (Van Bavel 1949). The mean weight diameter was summed over all 4 size fractions, including the one that passed the $0.25-\mathrm{mm}$ sieve

$$
\left(\mathrm{MWD}=\sum_{\mathrm{i}=1}^{4} \mathrm{~W}_{\mathrm{i}} \mathrm{D}_{\mathrm{i}}\right)
$$

Corrections were made for the coarse fraction retained on each sieve to avoid biased interpretations of water stable aggregates.

Intact soil samples were taken with a double-cylinder, drop-hammer sampler (with a core of $7.5 \times 7.5 \mathrm{~cm}$ ) for bulk density determination (Blake and Hartge 1986). One core was taken per sampling unit from $0-7.5,7.5-15$, and $15-30 \mathrm{~cm}$ depths on Tranquille, Dewdrop, and Harper sites, while stoniness restricted soil coring below $15 \mathrm{~cm}$ on Guichon site and below $7.5 \mathrm{~cm}$ on Quilchena site. Soil samples for bulk density determination were dried at $105^{\circ} \mathrm{C}$ for 48 hours in a forced-air oven. Coarse fragments (diameter $>2 \mathrm{~mm}$ ) within the sample were screened out and weighed. Volume of mineral coarse fragments was determined from dry mass and assumed to have a particle density of 2.65 $\mathrm{Mg} \mathrm{m}^{-3}$. Soil bulk density was calculated as the mass of dry, coarse, fragment-free mineral soil per volume of field-moist soil, where volume is also calculated on a coarse fragment-free basis.

Soil penetration resistance (Bradford 1986) was measured to $30 \mathrm{~cm}$ depth on Tranquille, Dewdrop, and Harper sites, to $12 \mathrm{~cm}$ depth on Guichon site, and to 10.5 $\mathrm{cm}$ depth on Quilchena site. Different depths determined were the result of soil stoniness. Measurements were recorded at depth intervals of $1.5 \mathrm{~cm}$, using a handpushed $13-\mathrm{mm}$ diameter cone $\left(30^{\circ}\right)$ penetrometer with data logger (Agridry Rimik PTY Ltd., Toowoomba, QLD, Australia). Three soil profiles were recorded on each of the 4 randomly selected sampling units.

Rate of water infiltration in the field was determined using a double-ring infiltrometer (Bouwer 1986). One measurement was done per sampling unit. Hence, at each site a total of 8 sets of cylinders (with an outer cylinder-56 cm diameter by $30 \mathrm{~cm}$ height and inner cylinder- $30 \mathrm{~cm}$ diameter by $30 \mathrm{~cm}$ height) were used. The cylinders were nested and pounded $5 \mathrm{~cm}$ into the ground forming a watertight seal. The change in water depth of the inner cylinder was measured over a period of 2 hours at time intervals of $5,10,15,20,30,40,50$, $60,75,90,105$, and 120 minutes. A head of $5-10 \mathrm{~cm}$ was maintained and readings were taken with a floating gauge. Conditions for the measurement of unsaturated hydraulic conductivity were assumed to occur after 20 minutes.

\section{Statistical Analyses}

Species cover, diversity index, evenness, and species number data were analyzed as randomized, complete block design with 5 replications (i.e., sites). Soil and root samples taken at consecutive depths from the same hole are dependent on each other. Hence, soil and root data were analyzed separately for each depth of sampling as a randomized, complete block design with 5 replications. The general linear model procedure in the SAS package (SAS Institute Inc. 1989) was used.

\section{Results}

\section{Vegetation}

Total plant cover and bare ground were similar for crested wheatgrass and native

Table 2. Botanical composition ( $\%$ cover) on crested wheatgrass and native rangelands.

\begin{tabular}{|c|c|c|c|}
\hline \multirow[b]{2}{*}{ Species } & \multicolumn{2}{|c|}{ Rangeland } & \multirow[b]{2}{*}{$P$} \\
\hline & Crested wheatgrass & Native grasses & \\
\hline & 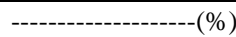 & ----------------- & \\
\hline \multicolumn{4}{|l|}{ Grasses } \\
\hline Bluebunch wheatgrass & 0.5 & 6.8 & 0.038 \\
\hline Crested wheatgrass & 23.4 & 1.1 & 0.000 \\
\hline Sandberg's bluegrass & 2.3 & 3.4 & 0.512 \\
\hline Needle-and-thread & 1.4 & 6.7 & 0.116 \\
\hline Junegrass & 0.4 & 2.2 & 0.349 \\
\hline Other grasses & 0.3 & 1.7 & 0.024 \\
\hline Total grasses & 28.3 & 21.9 & 0.028 \\
\hline \multicolumn{4}{|l|}{ Forbs } \\
\hline Dwarf pussytoes & 1.7 & 2.1 & 0.806 \\
\hline Other forbs & 1.2 & 3.7 & 0.075 \\
\hline Total forbs & 2.9 & 5.8 & 0.174 \\
\hline \multicolumn{4}{|l|}{ Shrubs } \\
\hline Big sagebrush & 1.4 & 7.8 & 0.109 \\
\hline Pasture sage & 0.7 & 1.1 & 0.493 \\
\hline Rabbit-brush & 0.8 & 1.5 & 0.332 \\
\hline Total shrubs & 2.9 & 10.5 & 0.034 \\
\hline Total cover & 34.5 & 37.6 & 0.493 \\
\hline Bare ground & 58.1 & 52.6 & 0.332 \\
\hline Diversity index & 0.98 & 1.70 & 0.010 \\
\hline Evenness & 0.37 & 0.76 & 0.002 \\
\hline Species number per $9.4 \mathrm{~m}^{2}$ & 14.0 & 17.0 & 0.470 \\
\hline
\end{tabular}

rangelands (Table 2). Cover of grasses was greater on crested wheatgrass than native rangeland, while the opposite was true for shrub cover. Forb cover was similar for the 2 rangelands.

Predominant species on native rangeland were big sagebrush, bluebunch wheatgrass, needle-and-thread, Sandberg's bluegrass (Poa secunda Presl.), and dwarf pussytoes (Antennaria dimorpha Nutt. T. $\&$ G.). Crested wheatgrass was the most abundant species on seeded rangeland with $23 \%$ of the total plant cover, while Sandberg's bluegrass, needle-and-thread, dwarf pussytoes, and big sagebrush together contributed $8 \%$ to total plant cover (Table 2). Species number was similar for crested wheatgrass and native rangelands, but diversity of crested wheatgrass rangeland was lower due to lower evenness.

Seeding of crested wheatgrass did not lead to reduction of root biomass relative to native rangeland (Table 3 ). Root biomass was similar for crested wheatgrass and native grasses at both $0-7.5$ and $7.5-15 \mathrm{~cm}$ depths. In addition, roots of the 2 grass communities contained similar amounts of $\mathrm{C}$ and $\mathrm{N}$ (Table 3 ).

\section{Soil}

Most soil properties were not affected by crested wheatgrass, although there were several exceptions. Soil C and N were marginally greater under crested wheatgrass than native grasses at the 2 
lower depths, i.e. 7.5-15 and 15-30 cm, (Table 4). Light fraction $\mathrm{C}$ was also greater with crested wheatgrass than native rangeland (Table 4). Total soil $\mathrm{P}$ at $15-30 \mathrm{~cm}$ depth was greater on native than on crested wheatgrass rangeland (Table 5). Available soil $\mathrm{K}$ at $0-7.5 \mathrm{~cm}$ depth was greater on crested wheatgrass than native rangeland (Table 5).

Soil aggregate stability parameters were not affected by crested wheatgrass seeding (Table 6). On both crested wheatgrass and native rangeland the smallest, $<0.25-\mathrm{mm}$ fraction, was the most dominant size fraction by making up about $50 \%$ of total soil aggregates. The largest, 2-6-mm size fraction, made up 26 to $30 \%$ of total soil aggregates on both rangelands.

Soil bulk density was similar under crested wheatgrass and native grasses at all 3 depths (Fig. 1a). Soil penetration resistance was also similar for the 2 grass communities with an exception at the 7.5 and $9 \mathrm{~cm}$ depths where it was greater on crested wheatgrass rangeland (Fig. 1b). No difference in the rate of water infiltration was observed between crested wheatgrass and native rangeland (Fig. 2).

\section{Discussion}

Low plant cover of both crested wheatgrass and native rangeland resulted from high utilization by cattle and limited soil water available for plant growth. Although native and crested wheatgrass rangelands were adjacent, the cover of crested wheatgrass was low on native rangeland (Table 2 ). This indicates that crested wheatgrass is not highly invasive on these rangelands. Crested wheatgrass did not deter reestablishment of native species to the degree reported in a mixed prairie of southern Alberta, dominated by Stipa-Bouteloua community, (Dormaar et al. 1978) or a sagebrush zone of southeastern Idaho (Marlette and Anderson 1986). The competitive ability of crested wheatgrass in our study was most likely reduced by heavy grazing allowing native species to establish. Native species, such as big sagebrush, Sandberg's bluegrass, needle-and-thread, and dwarf pussytoes, which established in crested wheatgrass rangeland, all have a high tolerance to grazing by cattle. On the other hand, establishment of bluebunch wheatgrass, which is not grazing tolerant, was restricted. In 2 earlier studies in Idaho (Hull and Klomp 1966, Marlette and Anderson 1986), big sagebrush was also one of the most abundant native species invading crested wheatgrass rangeland.
Table 3. Root biomass and root $\mathrm{C}$ and $\mathrm{N}$ contents of crested wheatgrass and native grasses.

\begin{tabular}{lcccc}
\hline \hline \multirow{2}{*}{ Root } & & \multicolumn{2}{c}{ Rangeland } & \\
\cline { 3 - 4 } Biomass & Depth $(\mathrm{cm})$ & Crested wheatgrass & Native grasses & $P$ \\
& $0-7.5$ & 2.4 & 2.6 & \\
& $7.5-15$ & 1.2 & 1.0 & 0.874 \\
C content & $\left.-----15{ }^{-1}\right)$ & 533 & 0.882 \\
& $0-7.5$ & 412 & 226 & 0.387 \\
N content & $7.5-15$ & 210 & 25 & 0.818 \\
& $0-7.5$ & 22 & 9 & 0.723 \\
\hline
\end{tabular}

Table 4. Soil properties of crested wheatgrass and native rangelands.

\begin{tabular}{|c|c|c|c|c|}
\hline \multirow[b]{2}{*}{ Soil property } & \multicolumn{3}{|c|}{ Rangeland } & \multirow[b]{2}{*}{$P$} \\
\hline & Depth $\overline{(\mathrm{cm})}$ & Crested wheatgrass & Native grasses & \\
\hline \multirow{3}{*}{ Total C } & --------------- & $\left(\mathrm{kg} \mathrm{m}^{-2}\right)$ & 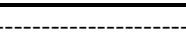 & \\
\hline & $0-7.5$ & 18.7 & 16.9 & 0.267 \\
\hline & $7.5-15$ & 14.6 & 12.4 & 0.072 \\
\hline \multirow{4}{*}{ Total N } & $15-30$ & 12.6 & 10.2 & 0.028 \\
\hline & $0-7.5$ & 1.7 & 1.5 & 0.133 \\
\hline & $7.5-15$ & 1.4 & 1.2 & 0.088 \\
\hline & $15-30$ & 1.2 & 1.0 & 0.053 \\
\hline \multirow{2}{*}{$\mathrm{C}$ as polysaccharides } & $0-7.5$ & 0.83 & 0.63 & 0.998 \\
\hline & $7.5-15$ & 0.59 & 0.52 & 0.202 \\
\hline Light fraction $\mathrm{C}$ & $0-7.5$ & 4.26 & 3.97 & 0.013 \\
\hline Light fraction $\mathrm{N}$ & $0-7.5$ & 1.08 & 1.09 & 0.904 \\
\hline
\end{tabular}

Table 5. Soil pH, total and available phosphorus, exchangeable cations, and cation exchange capacity (CEC) on crested wheatgrass and native rangelands.

\begin{tabular}{|c|c|c|c|c|}
\hline \multirow[b]{2}{*}{ Soil property } & \multicolumn{3}{|c|}{ Rangeland } & \multirow[b]{2}{*}{$P$} \\
\hline & Depth & Crested wheatgrass & Native grasses & \\
\hline & $(\mathrm{cm})$ & & & \\
\hline \multirow{3}{*}{$\mathrm{pH}\left(\mathrm{CaCl}_{2}\right)$} & $0-7.5$ & 6.4 & 6.4 & 0.914 \\
\hline & $7.5-15$ & 6.6 & 6.5 & 0.520 \\
\hline & $15-30$ & 6.7 & 6.6 & 0.399 \\
\hline \multirow[t]{3}{*}{ Total P } & $0-7.5$ & 0.08 & 0.09 & 0.399 \\
\hline & $7.5-15$ & 0.07 & 0.07 & 0.289 \\
\hline & $15-30$ & 0.07 & 0.09 & 0.031 \\
\hline \multirow{3}{*}{ Available P } & $0-7.5$ & 14.7 & 12.3 & 0.214 \\
\hline & $7.5-15$ & 13.9 & 12.6 & 0.711 \\
\hline & $15-30$ & 13.3 & 14.1 & 0.857 \\
\hline & & $\left(\mathrm{cmol}_{\mathrm{C}} \mathrm{kg}\right.$ & & \\
\hline \multirow[t]{3}{*}{$\mathrm{Ca}$} & $0-7.5$ & 8.45 & 7.94 & 0.563 \\
\hline & $7.5-15$ & 9.16 & 8.34 & 0.523 \\
\hline & $15-30$ & 10.13 & 9.66 & 0.854 \\
\hline \multirow[t]{3}{*}{ Mg } & $0-7.5$ & 6.46 & 6.06 & 0.482 \\
\hline & $7.5-15$ & 7.68 & 6.93 & 0.348 \\
\hline & $15-30$ & 8.75 & 7.29 & 0.136 \\
\hline \multirow[t]{3}{*}{ K } & $0-7.5$ & 1.79 & 1.57 & 0.041 \\
\hline & $7.5-15$ & 1.48 & 1.48 & 0.956 \\
\hline & $15-30$ & 1.30 & 1.37 & 0.614 \\
\hline \multirow[t]{3}{*}{$\mathrm{Na}$} & $0-7.5$ & 0.10 & 0.08 & 0.568 \\
\hline & $7.5-15$ & 0.16 & 0.11 & 0.246 \\
\hline & $15-30$ & 0.24 & 0.14 & 0.225 \\
\hline \multirow[t]{3}{*}{ CEC } & $0-7.5$ & 25.03 & 22.90 & 0.331 \\
\hline & $7.5-15$ & 25.51 & 23.69 & 0.315 \\
\hline & $15-30$ & 25.93 & 22.50 & 0.159 \\
\hline
\end{tabular}



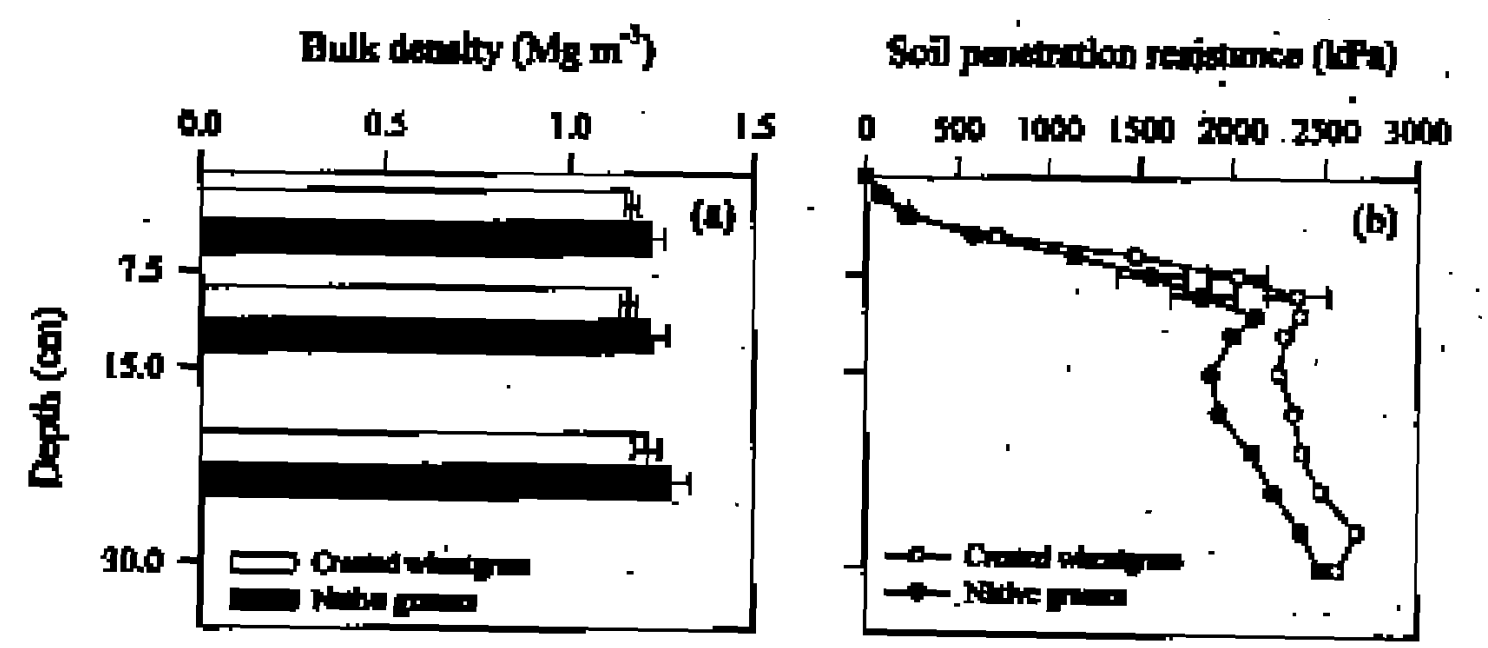

Fig. 1. Soil bulk density (a) and soil penetration resistance (b) on crested wheatgrass and native rangelands. Error bars represent standard error of the mean $(n=20)$ and they are shown on graph $(b)$ only on means that are significantly different $(P<0.05)$.

Several researchers (Wilson 1989, Lesica and DeLuca 1996) suggested that seeding with crested wheatgrass results in a less diverse plant community. Our study shows no reduction in species number on crested wheatgrass compared to native rangeland (Table 2), indicating that crested wheatgrass has not reduced plant diversity. Since crested wheatgrass was the most dominant species, while the remaining species were less abundant on the seeded rangeland than on the native rangeland, the Shannon-Weaver-diversity index was a better indicator of species diversity than species number. The diversity index was lower on crested wheatgrass rangeland indicating a less diverse plant community than on native rangeland. Nevertheless, crested wheatgrass did not completely prevent the establishment of grazing tolerant native species.

We found similar root biomass at both 0-7.5 and 7.5-15 cm depths with long-term grazing of crested wheatgrass and bluebunch wheatgrass rangeland (Table 3 ). In contrast, Smoliak et al. (1967) and

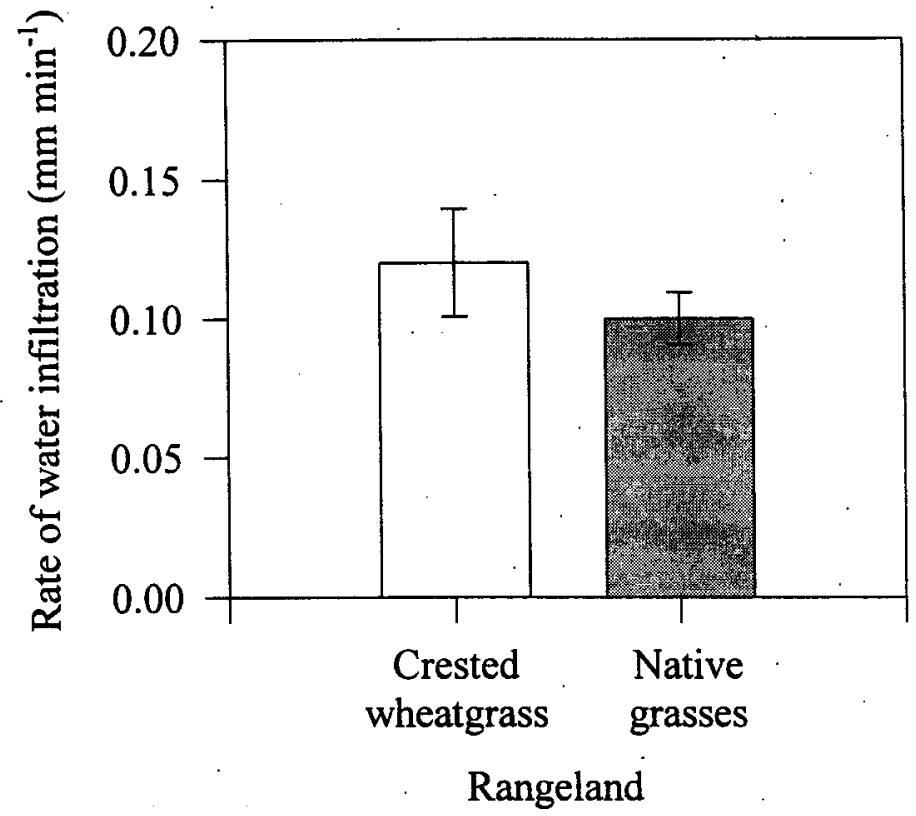

Fig. 2. Rate of water infiltration on crested wheatgrass and native rangelands. Error bars represent standard error of the mean $(n=20)$.
Dormaar et al. (1995) found that crested wheatgrass rangeland contained less root biomass than native rangeland dominated by blue grama and needle-and-thread in southern Alberta. Major cause for this disagreement is a difference in native grass species between southern Alberta and interior of BC. Different plant species composition in the 2 regions is, on the other hand, caused by different distribution of precipitation.

Higher total soil $\mathrm{C}$ at 7.5-15 and 15-30 cm depths (Table 4) in crested wheatgrass compared to native rangelands was probably due to the higher number of shrubs on native rangeland. Shrubs, having coarser roots than grasses, contribute less to the addition of total soil organic matter.

Long-term grazing, especially at high stocking rates, reduces soil structural stability and increases soil compaction (Warren et al. 1986, Dormaar and Willms 1998). Sites sampled during this study were grazed for more than a century before the seeding of crested wheatgrass and for 14 to 60 years after seeding. Hence, potential effects of crested wheatgrass seeding on soil aggregate stability and compaction were confounded by grazing. Soil bulk density, water infiltration rate, and most of the soil penetration resistance measurements were similar for crested wheatgrass and native rangelands (Fig. 1 and 2). Despite the fact that all these sites were grazed, differences in soil penetration resistance were observed at 7.5 and $9 \mathrm{~cm}$ depths, where it was greater on crested wheatgrass than native rangeland. Greater soil compaction on crested wheatgrass rangeland can be a result of earlier 
Table 6. Soil aggregate stability parameters on crested wheatgrass and native rangelands at 0-7.5 cm depth.

\begin{tabular}{|c|c|c|c|}
\hline \multirow[b]{2}{*}{ Species } & \multicolumn{2}{|c|}{ Rangeland } & \multirow[b]{2}{*}{$P$} \\
\hline & Crested wheatgrass & Native grasses & \\
\hline $2-6 \mathrm{~mm}$ & 26.2 & 29.7 & 0.455 \\
\hline $1-2 \mathrm{~mm}$ & 8.8 & 7.7 & 0.471 \\
\hline $0.25-1 \mathrm{~mm}$ & 13.6 & 9.9 & 0.370 \\
\hline$<0.25 \mathrm{~mm}$ & 51.5 & 52.7 & 0.799 \\
\hline Mean weight diameter & 1.3 & 1.4 & 0.546 \\
\hline
\end{tabular}

grazing of crested wheatgrass occurring under wetter soil conditions relative to grazing of native grasses.

This study shed some light on the impact of crested wheatgrass on rangeland soil and plant composition in the southern interior of British Columbia. Our findings show that seeding of crested wheatgrass did not lead to a monoculture, although the diversity of plant community was reduced relative to native rangeland. In addition, crested wheatgrass introduction accompanied with long-term grazing did not significantly change soil properties relative to the grazed native rangeland dominated by bluebunch wheatgrass. Responses of the rangeland soil to introduction of exotic grass species are strongly dependent on the rangeland vegetation and consequently they should be studied together to achieve sustainable range management.

\section{Literature Cited}

Anderson, J.E. and G.M. Marlette. 1986. Probabilities of seedling recruitment and the stability of crested wheatgrass stands. p. 97-103. In: K.L. Johnson (ed.) Crested wheatgrass: Its values, problems and myths. Symposium Proc. Utah State Univ., Logan, Ut.

Blake, G.R. and K.H. Hartge. 1986. Bulk density. In: A. Klute (ed.), Methods of soil analysis. Part 1 . Physical and mineralogical methods. Agron. 9:363-375. Amer. Soc. Agron., Madison, Wisc.

Bouwer, H. 1986. Intake rate: cylinder infiltrometer. In: A. Klute (ed.) Methods of soil analysis. Part 1. Physical and mineralogical methods. Agron. 9:825-844. Amer. Soc. Agron., Madison, Wisc.

Bradford, J.M. 1986. Penetrability. In: A. Klute (ed.) Methods of soil analysis. Part 1. Physical and mineralogical methods. Agron. 9:436-478. Amer. Soc. Agron., Madison, Wisc.

Daubenmire, R. 1959. A canopy-coverage method of vegetation analysis. Northw. Sci. 33:43-65.
De Jong, T.M. 1975. A comparison of three diversity indicies based on their components of richness and evenness. Oikos 26:222-227.

Dormaar, J.F. and W.D. Willms. 1998. Effect of forty-four years of grazing on fescue grassland soils. J. Range Manage. 51:122126

Dormaar, J.F., A. Johnston, and S. Smoliak. 1978. Long-term soil changes associated with seeded stands of crested wheatgrass in southeastern Alberta, Canada. p. 623-625. In: D.N. Hyder (ed.), Proc.1st Int. Rangeland Congress Soc. Range Manage., Denver, Colo.

Dormaar, J.F., M.A. Naeth, W.D. Willms, and D.S. Chanasyk. 1995. Effect of native prairie, crested wheatgrass (Agropyron cristatum (L.) Gaertn.) and Russian wildrye (Elymus junceus Fisch.) on soil chemical properties. J. Range Manage. 48:258-263.

Doutre, D.A., G.W. Hay, A. Hood, and G.W. VanLoon. 1978. Spectrophotometric methods to determine carbohydrates in soil. Soil Biol. Biochem. 10:457-462.

Dubois, M., K.A. Gilles, J.K. Hamilton, P.A. Rebers, and F. Smith. 1956. Colorimetric method for determination of sugars and relat ed substances. Anal. Chem. 28:350-356.

Environment Canada. 1998. Canadian climate normals 1961-1990. Kamloops airport meteorological records. HTTP://www. cmc.ec.gc.ca/climate/normals/BCK002.htm.

Gomm, F.B. 1981. Letter on the value of crest ed wheatgrass. Encl. 3-7. In: G. Ferry et al. Washington range seeding program. USDI Bur. Land Manage., Portland, Ore.

Gregorich, E.G. and B.H. Ellert. 1993. Light fraction and microorganic matter in mineral soils. p. 397-407. In: M.R. Carter (ed.) Soil sampling and methods of analysis. Can. Soc. Soil Sci., Lewis Publ., Boca Raton, Fla.

Hull, A.C. and G.J. Klomp. 1966. Longevity of crested wheatgrass in the sagebrush-grass type in southern Idaho. J. Range Manage. 19:5-11.

Lesica, P. and T.H. DeLuca. 1996. Long-term harmful effects of crested wheatgrass on Great Plains grassland ecosystems. J. Soil Water Conserv. 51:408-409.

Looman, J. and D.H. Heinrichs. 1973. Stability of crested wheatgrass pastures under long-term pasture use. Can. J. Plant Sci. 53:501-506. (ed.) Review of the Bureau's Oregon and
Marlette, G.M. and J.E. Anderson. 1986. Seed banks and propagule dispersal in crested-wheatgrass stands. J. Appl. Ecol. 23:161-175

McLean, E.O. 1982. Soil pH and lime requirement. In: A.L. Page, R.H. Miller, and D.R. Keeney (ed.) Methods of soil analysis. Part 2. Chemical and microbiological properties. Agron. 9:199-224. Amer. Soc. Agron., Madison, Wisc.

Nelson, D.S. and L.E. Sommers. 1982. Total carbon, organic carbon, and organic matter. p. 539-579. In: A.L. Page, R.H. Miller, and D.R. Keeney (ed.) Methods of soil analysis. Part 2. Chemical and microbiological properties. Agron. 9:539-579. Amer. Soc. Agron., Madison, Wisc.

Olsen, S.R., C.V. Cole, F.S. Watanabe, and L.A. Dean. 1954. Estimation of available phosphorus in soils by extraction with sodium bicarbonate. USDA, Circ. 939, U.S. Government Printing Office, Washington, D.C.

Parkinson, J.A. and S.E. Allen. 1975. A wet oxidation procedure suitable for the determination of nitrogen and mineral nutrients in biological materials. Commun. Soil Sci. Plant Anal. 6:1-11.

Pileou, E.C. 1966. The measurement of diversity in different types of biological collections. J. Theor. Biol. 13:131-144.

SAS Institute Inc. 1989. SAS/STAT user's guide. Version 6, 4th ed., Vol.2. SAS Inst. Inc., Cary, N.C.

Shannon, C.E. and W. Weaver. 1949. The mathematical theory of communication. Univ. of Illinois Press, Urbana, Ill.

Smoliak, S., A. Johnston, and L.E. Lutwick. 1967. Productivity and durability of crested wheatgrass in southeastern Alberta. Can. J. Plant Sci. 47:539-548.

Soil Survey Laboratory Staff. 1992. Soil survey laboratory methods manual. Soil Surv. Invest. Reps. 42. USDA-SCS, Washington, D.C.

Van Bavel, C.H.M. 1949. Mean weight diameter of soil aggregates as a statistical index of aggregation. Soil Sci. Soc. Am. Proc. 14:2023.

Warren, S.D., M.B. Nevill, W.H. Blackburn, and N.E. Garza. 1986. Soil response to trampling under intensive rotation grazing. Soil Sci. Soc. Amer. J. 50:1336-1341.

Wilson, S.D. 1989. The suppression of native prairie by alien species introduced for revegetation. Landscape and Urban Planning 17:113-119.

Yoder, R.E. 1936. A direct method of aggregate analysis of soils and study of the physical nature of soil erosion losses. Amer. Soc. Agron. J. 28:337-351. 